\title{
Radiological Analysis of Frontal Cells and its Association with Frontal Sinus Mucosal Disease: A Tertiary Care Hospital Based Study
}

\author{
Bikash Lal Shrestha, ${ }^{1}$ Sameer Karmacharya ${ }^{1}$
}

\begin{abstract}
Introduction
The frontal sinus and frontal recess both have complex anatomy causing difficulty during endoscopic sinus surgeries. The term frontal cells is currently used to describe a group of anterior ethmoidal cells classified by Kuhn et al into 4 types. Though there are precise descriptions, the frequency of frontal sinus cells (FSCs) varies widely in the literature. The presence of FSCs is responsible for a narrowing of the frontal sinus outflow tract which subsequently causes a partial obstruction of drainage and aeration of the frontal sinus. Our main aim is to the see the distribution of different frontal cells in Nepali population and relation with frontal sinus mucosal disease.

Materials and Methods

This prospective, longitudinal study performed in 110 consecutive patients who underwent CT scan of nose and paranasal sinuses. The frontal cells and agger nasi cells were identified and association between the frontal cells and agger nasi cells with frontal sinus mucosal disease was analyzed with chi square test.

$\underline{\text { Results }}$

The agger nasi was present in $83.63 \%$ CT scans whereas frontal cells were distributed in $61.82 \%$ CT (computed tomogram) scans. There was not statistical significance and any association between the frontal cells and agger nasi cells with frontal sinus mucosal disease.

Conclusion

The frontal cells and agger nasi cells distribution in Nepalese population, even though in small sample size, is similar with other studies in the literature. There is also non association of either frontal cells or agger nasi cells with frontal sinus mucosal disease.

$\underline{\text { Kevwords }}$
\end{abstract}

$\underline{\text { ABSTRACT }}$

Frontal Sinus; Tomography, X-Ray Computed; Frontal Cells

$\mathrm{T}$ The frontal sinus and frontal recess both have complex anatomy causing surgeons difficulty during endoscopic sinus surgeries. So, preoperative computed tomographic (CT) scan is mandatory to know the types of frontal cells and also other anatomic variations of paranasal sinuses. ${ }^{1}$

The frontal recess is basically an hour-glass structure through which the secretions of frontal sinus drain. Frontal sinus anatomy was first described by Schaeffer in 1916. ${ }^{2}$ But Bent and Kuhn were the first to describe four distinct types of Frontal Sinus Cells (FSCs) in $1994 .^{3}$ The term frontal cells (frontoethmoidal cells) is currently used to describe a group of anterior ethmoidal cells that have been classified by Kuhn et al into 4 types. ${ }^{3}$ Type I is a single frontal cell above an agger nasi cell. Type II is a group of cells in the frontal recess above the agger nasi. Type III is a pneumatized large cell from the frontal recess into the frontal sinus. Type IV is isolated cell inside frontal sinus. Frontal cells have been reported to occur in $20-41 \%$ of paranasal sinuses. ${ }^{4}$ Though there are precise

1 - Department of ENT, Dhulikhel Hospital, Kathmandu University Hospital, Kavre, Nepal

Corresponding author:

Dr Bikash Lal Shrestha

email: bikash001@hotmail.com 
descriptions, the frequency of FSCs varies widely in the literature. ${ }^{3,5,6}$ The variation could be explained by differences in patient population examined, or, perhaps, because of confusion surrounding nomenclature. ${ }^{1}$

The presence of FSCs is responsible for a narrowing of the frontal sinus outflow tract which subsequently causes a partial obstruction of drainage and aeration of the frontal sinus. Despite this, frontal sinus mucosal disease (as observed by mucosal thickening $>3 \mathrm{~mm}$ ) has only been previously associated in FSC types 3 and $4 .^{7}$

Till now there had been no such study regarding analysis of different frontal cells in Nepali population. So our main aim is to the see the distribution of different frontal air cells in Nepali population and also relation with frontal sinus mucosal diseases.

\section{Materials and Methods}

This was the cross sectional study conducted in the Department of Otorhinolaryngology and Head and Neck Surgery, in a tertiary care teaching hospital in Nepal from 1st January 2018 to 30th April 2018. The ethical approval was taken from institutional review committee.

All patients aged 18 years and above who underwent Computed tomographic scans (CT Scan) of the nose and paranasal sinuses were included in the study whereas patient with previous sinus surgery, age $<18$ years, maxillofacial trauma, sinonasal malignancy, congenital anomaly and CT images of low resolution were excluded. Other types of frontal recess cells like inter frontal sinus septal cells, supraorbital cells, suprabullar cells, and frontal bulla cells were not included in this study.

110 consecutive patients who underwent CT scan of nose and paranasal sinuses and fits in the inclusion criteria were taken for the study.

CT scans were done in a 128 slice machine. Patient was positioned in supine position and using the parameters- $130 \mathrm{kV}, 145 \mathrm{mAs}$, and scan time of 3.5 seconds, a volumetric axial CT scan was taken with 3 $\mathrm{mm}$ slices thickness from the frontal sinus to the floor of maxillary sinus. Multiplanar reconstruction was done using $1 \mathrm{~mm}$ thin slices with $0.5 \mathrm{~mm}$ interval and images were obtained in all planes. The scans were studied to identify the different types of anatomical variations mainly identifying the agger nasi and the frontal cells as classified by Kuhn et al. ${ }^{3}$ The cells were identified on the right and left sides separately on each side. Likewise, Lund - Mackay scoring system was used with score $0-2$ for the frontal sinus mucosal disease. Score $0-$ no opacity, 1 - partial opacity and 2 - total opacity. 8 We have used score 1 and 2 as mucosal disease.

For the statistical analysis, statistical package for social sciences version 23 (SPSS) was used.

Chi square test was used to analyze the statistical significance and association between agger nasi cells with frontal sinus mucosal disease and frontal cells with frontal sinus mucosal disease. Similarly, the frequency table was used to evaluate the frequency of gender, frontal cells and agger nasi cells. The $\mathrm{p}$ value of $<.05$ was taken as significant.

\section{Results}

There were total 110 CT scans included for the study. The age distribution was minimum 18 years to maximum 71 years with mean age of 54+/-14.44 years.

Regarding the gender distribution, both the male and female were equal in number (55 each).

Table I: The bilateral total distribution of frontal cells

\begin{tabular}{|c|c|c|}
\hline $\begin{array}{c}\text { TOTAL } \\
\text { FRONTAL } \\
\text { CELLS } \\
\text { BILATERAL }\end{array}$ & FREQUENCY & PERCENT \\
\hline Absent & 84 & 38.18 \\
\hline type I & 42 & 19.09 \\
\hline type II & 38 & 17.27 \\
\hline type III & 45 & 20.45 \\
\hline type IV & 11 & 5 \\
\hline Total & 220 & 100 \\
\hline
\end{tabular}




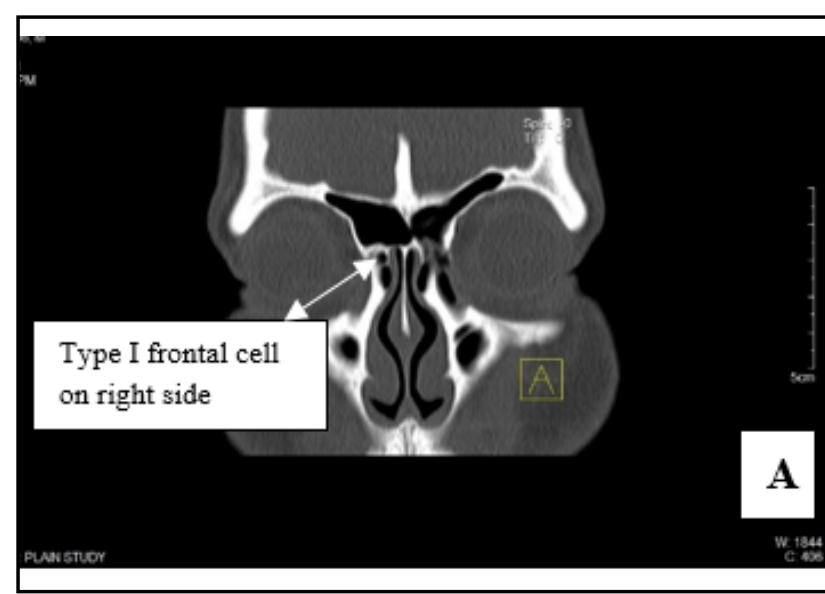

Fig.1. (A) Type I frontal cell on right side shown with arrow.

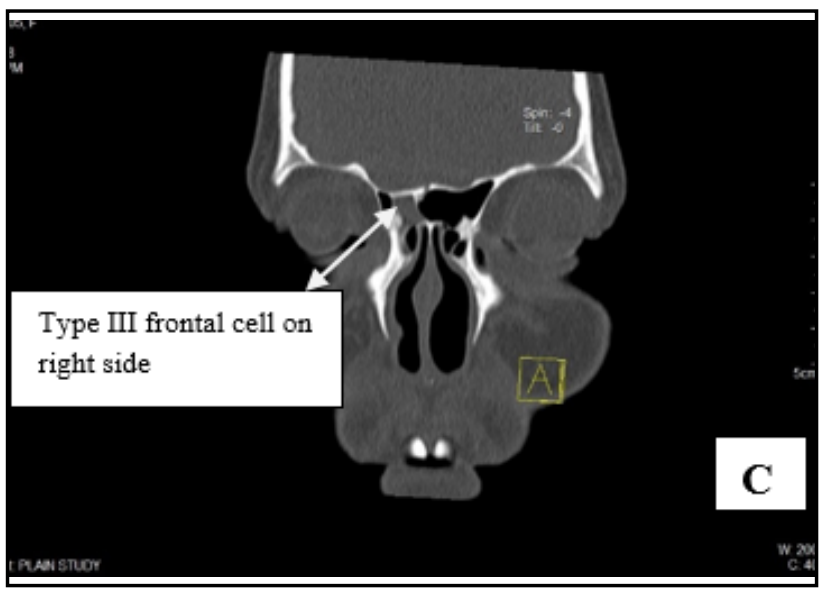

Fig.1. (C)Type III frontal cells on right side shown with arrow.

The different types of frontal cells are as shown in Fig. 1 A, B, C and D.

The bilateral distribution of frontal cells showed that it was present in $61.82 \%$ as shown in Table I.

Agger nasi cells were present in $83.63 \%$ as shown in Table II.

The Table III shows the cross tabulation between right frontal cells with right frontal sinus mucosal disease which was not statistically significant and also not associated.

Similarly, the Table IV showed the cross tabulation between left frontal cells with left frontal sinus mucosal disease which was not statistically significant and also

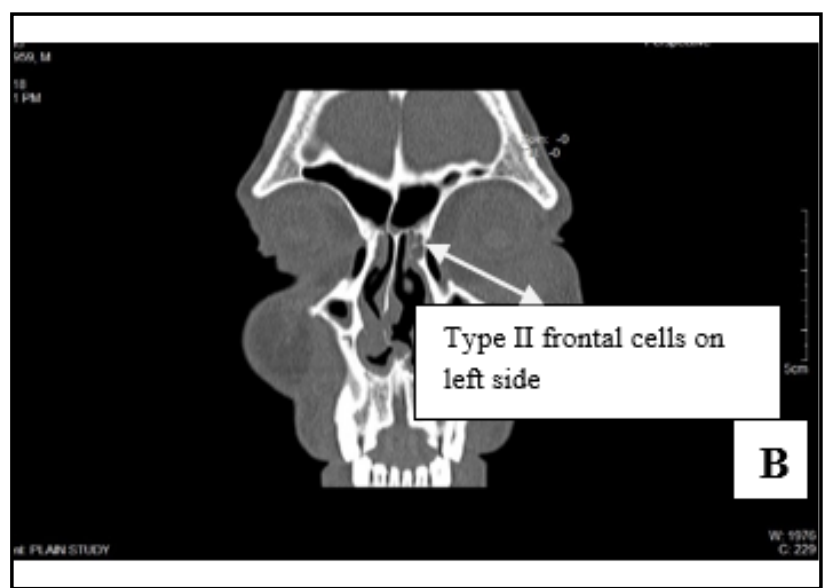

Fig.1. (B) Type II frontal cell on left side shown with arrow.

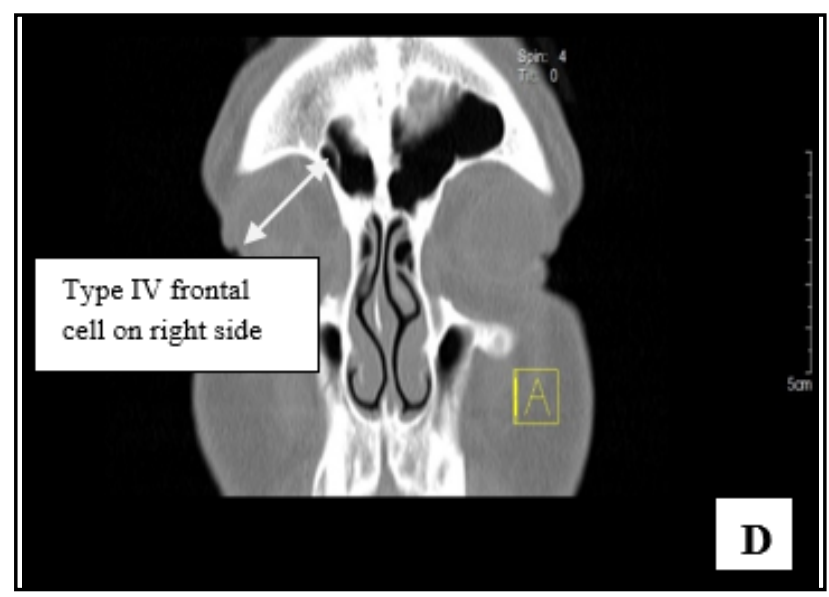

Fig.1. (D)Type IV frontal cells on right side shown with arrow.

not associated.

Table II: The distribution of agger nasi cells.

\begin{tabular}{|c|c|c|}
\hline $\begin{array}{c}\text { TOTAL } \\
\text { AGGER NASI }\end{array}$ & FREQUENCY & PERCENT \\
\hline Present & 184 & 83.63 \\
\hline Absent & 36 & 16.36 \\
\hline Total & 220 & 100 \\
\hline
\end{tabular}


Table III: Cross tabulation count between right frontal cells and right frontal sinus mucosal disease.

\begin{tabular}{|c|c|c|c|c|}
\hline \multicolumn{2}{|c|}{} & \multicolumn{2}{|c|}{$\begin{array}{r}\text { FRONTAL SINUS MUCOSAL } \\
\text { DISEASE RIGHT }\end{array}$} & TOTAL \\
\cline { 3 - 5 } & \multicolumn{2}{|c|}{ PRESENT } & ABSENT & \\
\hline \multirow{4}{*}{$\begin{array}{c}\text { Frontal cells } \\
\text { Right }\end{array}$} & Absent & 16 & 21 & 37 \\
\cline { 2 - 6 } & type I & 6 & 14 & 20 \\
\cline { 2 - 6 } & type II & 7 & 12 & 24 \\
\hline & type III & 12 & 4 & 5 \\
\cline { 2 - 6 } & type IV & 1 & 68 & 110 \\
\hline
\end{tabular}

Table IV: Cross tabulation count between left frontal cells and left frontal sinus mucosal disease. $(\mathbf{n}=110)$

\begin{tabular}{|c|c|c|c|c|}
\hline & & \multicolumn{2}{|c|}{$\begin{array}{c}\text { FRONTAL SINUS MUCOSAL } \\
\text { DISEASE LEFT }\end{array}$} & \multirow{2}{*}{ TOTAL } \\
\hline & & PRESENT & ABSENT & \\
\hline \multirow{5}{*}{$\begin{array}{l}\text { Frontal cells } \\
\text { Left }\end{array}$} & Absent & 21 & 26 & 47 \\
\hline & type I & 8 & 14 & 22 \\
\hline & type II & 8 & 6 & 14 \\
\hline & type III & 9 & 12 & 21 \\
\hline & type IV & $\mathbf{0}$ & 6 & 6 \\
\hline \multicolumn{2}{|c|}{ Total } & 46 & 64 & 110 \\
\hline
\end{tabular}

Chi-square test $=6.100 ; p=0.192 ;$ Non- significant

Linear by linear association $=.838 ; p=0.360 ;$ Non-significant 
Table V: Cross tabulation count between left agger nasi cells with left frontal sinus mucosal disease.

\begin{tabular}{|c|c|c|c|c|}
\hline \multicolumn{2}{|c|}{} & \multicolumn{2}{|c|}{$\begin{array}{r}\text { FRONTAL SINUS MUCOSAL } \\
\text { DISEASE LEFT }\end{array}$} \\
\cline { 3 - 5 } & \multicolumn{2}{|c|}{ TOTAL } \\
\cline { 3 - 5 } Agger Nasi Left & Present & 37 & 53 & 90 \\
\cline { 2 - 5 } & Absent & 9 & 11 & 20 \\
\hline \multirow{2}{*}{ Total } & & 46 & 64 & 110 \\
\hline
\end{tabular}

Chi- square test $=0.102 ; p=0.750 ;$ Non-significant

Linear by linear association $=0.101 ; p=0.751 ;$ Non-significant

Table VI: Cross tabulation count between right agger nasi cells with right frontal sinus mucosal disease.

\begin{tabular}{|c|c|c|c|c|}
\hline \multicolumn{2}{|c|}{} & \multicolumn{2}{|c|}{$\begin{array}{r}\text { FRONTAL SINUS MUCOSAL } \\
\text { DISEASE RIGHT }\end{array}$} & TOTAL \\
\cline { 3 - 5 } & \multicolumn{2}{|c|}{ PRESENT } & ABSENT & \\
\hline \multirow{2}{*}{ Agger Nasi Right } & Present & 34 & 60 & 94 \\
\cline { 2 - 5 } & Absent & 8 & 8 & 16 \\
\hline \multirow{2}{*}{ Total } & & 42 & 68 & 110 \\
\hline
\end{tabular}

Chi- square test $=1.108 ; p=0.293 ;$ Non-significant

Linear by linear association $=1.098 ; p=0.295$; Non-significant

Likewise, the Tables V and VI showed the cross tabulation between left agger nasi with left frontal sinus mucosal disease and right agger nasi with right frontal sinus mucosal disease and there was not any association and statistical significance.

\section{Discussion}

The frontal recess is a complex anatomical space that resembles an inverted cone, with the apex directed towards the frontal ostium. The frontal isthmus is filled by various anterior ethmoid or frontal recess cells. ${ }^{3}$ The complex anatomy makes this space mandatory for comprehensive knowledge of frontal recess anatomy prior to surgery. The different views of CT scan (axial, coronal and sagittal views) make it easier to know the detail knowledge of frontal recess anatomy.

Our study showed that the frequency of agger nasi was $83.63 \%$ which is comparable with other studies in the literature which showed the prevalence of agger nasi 
cells ranges from $52.87 \%$ to $94.1 \%$ respectively. ${ }^{5,8-12}$ This shows the variation in pneumatisation of agger nasi cells in different population and different races.

The frequency of frontal cells in our study was $61.82 \%$ which is similar to study performed by Eweiss et al. ${ }^{13}$ which showed the frequency of frontal cells around $78.57 \%$. But this is higher than the other studies which showed the prevalence of frontal cells ranges from 20$41 \%$ respectively. ${ }^{7,14,15}$ The reason behind such high frequency of frontal cells could be different variation of races within our community and we had also included cells as frontal cells as named by Kuhn et al. ${ }^{3}$

Regarding the distribution of frontal cells, our study showed that the type I frontal cells $19.09 \%$, type II $17.27 \%$, type III $20.45 \%$ and type IV $5 \%$. Other studies also showed the marked variation of different frontal cells with type I cells were found in $13.6-28 \%$ of sinuses, type II cells were found in $2-14 \%$, type III cells were found in $1.9-11 \%$, and type IV cells were found in $0-3.1 \%{ }^{4,6,9-11,16,17}$ The type III cells are somehow higher in our study, the reason could be because of different variation races in our community from Mongols to Aryans.

Regarding association of frontal sinus mucosal disease with agger nasi cells and frontal cells, our study showed no significant association which is similar to other studies., ${ }^{413}$ However, another study showed an association between FSCs and frontal mucosal thickening only to be statistically significant in type 3 and type 4 cells. $^{7}$

The reason behind our study could be apart from the anatomic variations in the frontal recess causing frontal sinus pathology, mucosal inflammation are also possible etiology. ${ }^{418}$ Seven major factors were explained in literature as associated with frontal sinus pathology and they are: mucosal disease $(67 \%)$; presence of ethmoid cells (53\%); lateralization of middle turbinates (30\%); presence of agger nasi cells (13\%); scar tissue (12\%); presence of frontal cells $(8 \%)$; and neo-osteogenesis ( $7 \%$ ), with most frontal recesses having more than one factor (average 1.6). ${ }^{19}$ These could be the reason for non-association of frontal sinus mucosal disease with frontal cells or agger nasi cells in our study.

This is the first time we are exploring the agger nasi and frontal cell types in Nepali population, even in small group, and also association with frontal sinus mucosal disease. So, we are somehow able to find the variation in frontal cells and agger nasi cells and association with frontal sinus mucosal disease in Nepali population, even though it is in small sample size. This is quiet new in Nepali population as these sort of study not done in Nepal previously.

The major limitation of the study is we had not included all frontal cell system for the analysis of frontal sinus disease. Moreover it will be more reliable if we analyze the different frontal cells with clinical and radiological findings. The further study in large sample size of population is required to know the distribution of frontal cells and also association with frontal sinusitis using both clinical and radiological criteria. Probably this will fulfill with multicentric study within different institutions of Nepal.

\section{Conclusion}

This is the first study on the distribution of the he frontal cells and agger nasi cells in Nepalese population. Even though the sample size is small, the incidence has been found to be similar with other studies in the literature. There is also non association of either frontal cells or agger nasi cells with frontal sinus mucosal disease.

\section{References}

1. Langille M, Walters E, Dziegielewski PT, Kotylak T, Wright ED. Frontal sinus cells: identification, prevalence, and association with frontal mucosal thickening. Am J Rhinol Allergy. 2012; 26(3):e107-10

2. Schaeffer J. The genesis, development and adult anatomy of the nasofrontal region in man. Am J Anat. 1916; 20:125-46

3. Bent J, Cuilty-Siller C, Kuhn FA. The frontal sinus cell as a cause of frontal sinus obstruction. Am J Rhinol. 1994; 8:185-91

4. DelGaudio JM, Hudgins PA, Venkatraman G, and Beningfield A. Multiplanar computed tomographic analysis of frontal recess cells: Effect on frontal isthmus size and frontal sinusitis. Arch Otolaryngol Head Neck Surg. 2005; 131:230-35

5. Lee WT, Kuhn FA, and Citardi MJ. 3D computed tomographic analysis of frontal recess anatomy in patients without frontal sinusitis. Otolaryngol Head Neck Surg. 2004; 131: 164-73

6. Woo HJ YS, Bae CH, Song SY, and Kim YD. Anatomic variations of the frontal recess and frontal sinusitis: Computed 
tomographic analysis. J Rhinol. 2009; 16: 20-5

7. Meyer TK, Kocak M, Smith MM, and Smith TL. Coronal computed tomography analysis of frontal cells. Am J Rhinol. 2003; $17: 163-8$

8. Lund VJ and Mackay IS. Staging in rhinosinusitus. Rhinology 1993; 31(4):183-84

9. Cho JH, Citardi MJ, Lee WT, Sautter NB, Lee HM, Yoon JH, et al. Comparison of frontal pneumatization patterns between Koreans and Caucasians. Otolaryngol Head Neck Surg. 2006; 135:780-6

10. Han D, Zhang L, Ge W, Tao J, Xian J, Zhou B. Multiplanar computed tomographic analysis of the frontal recess region in Chinese subjects without frontal sinus disease symptoms. ORL J Otorhinolaryngol Relat Spec. 2008; 70:104-12

11. Kabota K, Takeno S, Hirakawa K. Frontal recess anatomy in Japanese subjects and its effect on the development of frontal sinusitis: computed tomographic analysis. J Otolaryngol Head Neck Surg. 2015; 44:21-6

12. Krzeski A, Tomaszewska E, Jakubczyk I, Galewicz-Zieli'nska A. Anatomic variations of the lateral nasal wall in the computed tomography scans of patients with chronic Rhinosinusitis. Am J Rhinol. 2001; 15(6):371-5
13. Eweiss AZ, Khalil HS. The prevalence of frontal cells and their relation to frontal sinusitis: a radiological study of the frontal recess area. ISRN Otolaryngol. 2013; 24:687512.

14. Van Alyea OE. Frontal cells: an anatomic study of these cells with consideration of their clinical significance. Arch Otolaryngol. 1941; 34:11-23

15. McLaughlin RB, Rehl RM, Lanza DC. Clinically relevant frontal sinus anatomy and physiology. Otolaryngol Clin North Am. 2001; 34:1-22

16. Thomas L, and Pallanch JF. Three-dimensional CT reconstruction and virtual endoscopic study of the ostial orientations of the frontal recess. Am J Rhinol Allergy 2010; 24:378-84

17. Park SS, Yoon BN, Cho KS, and Roh HJ. Pneumatization pattern of the frontal recess: Relationship of the anterior-toposterior length of frontal isthmus and/or frontal recess with the volume of agger nasi cell. Clin Exp Otorhinolaryngol. 2010; 3:76-83

18. Han JK, Tamer G, Lee B, Gross CW. Various causes for frontal sinus obstruction. Am J Otolaryngol. 2009; 30:80-2

19. Otto KJ, DelGaudio JM. Operative findings in the frontal recess at time of revision surgery. Am J Otolaryngol. 2010; 31:175-80. 